\title{
Faktor-faktor yang Mempengaruhi Petani dalam Menerapkan Standar Operasional Prosedur (SOP) Sistem Pertanian Organik di Kabupaten Bandung Barat
}

\section{Factors Affecting Farmers in Applying Standard Operational Procedure (SOP) of Organic Farming System in Bandung Barat Regency}

\author{
Anne Charina ${ }^{1}$, Rani Andriani Budi Kusumo ${ }^{1}$, Agriani Hermita Sadeli ${ }^{1}$, Yosini Deliana ${ }^{1}$ \\ 'Program Studi Agribisnis, Fakultas Pertanian Universitas Padjadjaran
}

\begin{abstract}
In Bandung Barat regency, many vegetable farmers have started organic farming, but some do not run fully organic vegetable farming system according to the SOP (standard operating procedure). This study aims to analyze the level of organic farming system in application and to determine the factors that affect farmers in adopting organic farming system. The study was conducted in three sub-districts in Bandung Barat regency: Lembang, Parongpong and Cisarua sub-districts. The sample consisted of 105 farmers who grow organic vegetables. Data were analyzed descriptively, using a multiple linear regression analysis. The results showed that the application of organic farming system is still at a moderate level. Factors affecting farmers in applying the SOP of organic farming system were th efarmers' educational level, participation in extension activities, perceptions of the relative advantage, complexity and observability of organic vegetables farming system. Support for extension activities is needed to improve farmers knowledge and skills in organic vegetables farming according to SOP and improve access to the organic vegetable market.
\end{abstract}

Keywords: farmers, vegetables, organic, application, affect

\section{Abstrak}

Di Kabupaten Bandung Barat banyak petani sayuran yang mulai menjalankan pertanian organic, namun masih terdapat petani yang belum sepenuhnya menjalankan sistem budidaya sayuran organic sesuai dengan SOP. Tujuan dari penelitian ini adalah untuk mengetahui bagaimana penerapan SOP sistem pertanian organic yang dilakukan oleh petani sayuran organic di Kabupaten Bandung Barat serta faktor-faktor yang mempengaruhi petani dalam menerapkan SOP sistem pertanian organic. Penelitian dilakukan di tiga kecamatan di Kabupaten Bandung Barat, yaitu Kecamatan Lembang, Parongpong dan Cisarua. Responden dalam penelitian ini adalah 105 orang petani yang membudidayakan sayuran organic. Data dianalisis secara deskriptif dan analisis regresi linier berganda. Hasil penelitian menunjukkan tingkat penerapan SOP sistem pertanian organic masih tergolong sedang. Faktor yang mempengaruhi petani dalam menerapkan SOP sistem pertanian organic adalah tingkat pendidikan petani, keikutsertaan petani dalam kegiatan penyuluhan, persepsi petani terhadap keuntungan relative, tingkat kerumitan dan keteramatan dari budidaya sayuran organic. Dukungan kegiatan penyuluhan sangat diperlukan untuk meningkatkan pengetahuan dan keterampilan petani dalam membudidayakan sayuran organic sesuai dengan SOP serta meningkatkan akses ke pasar sayuran organik.

Kata kunci : petani, sayuran, organic, penerapan, pengaruh

\section{Pendahuluan}

Pertanian berkelanjutan merupakan suatu tantangan dalam dunia pertanian, yang menuntut petani untuk memiliki perilaku usahatani yang berbeda dan lebih baik terutama untuk aspek lingkungan. Hal ini ternyata tidaklah mudah, sebab jika diamati saat ini yang ditemukan bahwa petani masih tinggi sekali faktor ketergantungannya terhadap unsur-unsur kimiawi dalam kegiatan usaha taninya. Penerapan pertanian organik secara utuh dirasakan tidak mudah bagi petani.
Salah satu sistem pertanian yang merupakan implementasi dari sistem pertanian berkelanjutan adalah sistem pertanian organik. Sistem pertanian organik telah mengalami perkembangan pesat di negara-negara Eropa dan Amerika. Laju penjualan pangan organik di negara-negara tersebut berkisar dari $20-25 \%$ pertahun selama dekade terakhir (Zulvera, 2014).

Indonesia sebagai negara agraris memiliki peluang dan potensi besar untuk mengembangkan pertanian organik. Dengan memiliki 17 juta hektar lahan kosong dan masih luasnya pertanian 
tradisional yang dikelola tanpa menggunakan bahan sintetis, menjadi salah satu modal penting untuk mengembangkan pertanian organik. Berdasarkan data statisitik total luas area pertanian organik Indonesia tahun 2012 adalah 213.023,55 ha yang tersebar di 15 Provinsi di Indonesia.

Pemerintah pun mendukung trend pertanian organik dengan mengeluarkan kebijakan pemerintah yang disebut Go Organik 2010. Beberapa kebijakan lainnya yang tercantum dalam Program Nawacita diantaranya sampai dengan tahun 2020, pemerintah Indonesia mencanangkan pembentukan 1000 Desa Organik, yang terdiri dari 600 Desa Organik Pangan, 250 Desa Organik Horti dan 150 Desa Organik Perkebunan. Saat ini di Indonesia sendiri trend komsumsi produk organik mengalami peningkatan yang cukup signifikan antara $20-25$ persen pertahun.

Pertanian organik merupakan salah satu sistem bertani yang akan mampu menggiring petani untuk lebih peduli pada lingkungan dan memperhatikan faktor lingkungan dalam setiap aktivitas usaha tani yang dijalankan. Salah satu komponen yang bisa ditekan oleh petani jika dia menerapkan pertanian organik diantaranya adalah biaya pemberantasan hama serta pemupukan. Selama ini biaya pemberantasan hama dengan bahan kimiawi serta pemupukan kimiawi merupakan komponen biaya yang menyedot rupiah sangat besar bagi petani. Apabila biaya produksi dapat dikurangi, tentu harga produk yang dihasilkan akan lebih kompetitif, sehingga petani akan memiliki daya kompetisi yang lebih baik dengan produkproduk sejenis lainnya.

Sayuran sebagai salah satu produk hortikultura merupakan salah satu subsektor non pangan utama yang sangat rentan dengan penggunaan zat kimia. Jika kita melihat peluang bisnis, permintaan terhadap sayuran organik dewasa ini di negara kita luar biasa tinggi. Hal ini menjadi peluang besar yang harus segera ditangkap oleh petani untuk mendapatkan benefit maximal. Program pengenalan pertanian organik sebenarnya sudah banyak diberikan oleh pemerintah melalui berbagai kegiatan sosialisasi organik. Sayangnya kenyataan di lapangan tidak mudah mengajak petani untuk menerapkan pertanian organik. Salah satu contohnya dalam dosis penggunaan pupuk kimia, mereka masih menggunakan dosis di atas $300 \mathrm{~kg} / \mathrm{ha}$.
Jika mengacu pada SOP Sistem Pertanian Organik, hal ini jelas tidak sesuai dengan SOP.

Keputusan petani untuk mengadopsi suatu inovasi memang tidak mudah, karena banyak faktor yang mempengaruhinya. Jika melihat pada karakteristik petani yang cenderung menyukai zona aman, menghindari risk taking, dan berpikir rasional, maka hal ini menjadi sesuatu yang masuk akal. Inilah yang menjadi salah satu hambatan utama banyaknya program pertanian organik dari pemerintah menjadi tidak tepat sasaran. Jika pun ada beberapa petani yang proaktif menunjang program tersebut, penyebaran informasi serta pencapaian tujuan inovasi didapatkan dengan tidak mudah karena berbagai keterbatasan petani.

Di Kabupaten Bandung Barat sudah banyak petani sayuran yang mulai menjalankan pertanian organik. Beberapa di antara mereka bahkan telah berhasil mendapatkan Sertifikat Organik dari lembaga nasional maupun internasional. Fenomena yang menarik untuk dikaji adalah ternyata meskipun banyak dari mereka yang mengklaim sudah menerapkan pertanian organik, namun pada prakteknya input-input kimiawi masih digunakan dalam aktivitas usahatani mereka.

Beragam penelitian menjelaskan keputusan seseorang dalam mengadopsi inovasi dipengaruhi oleh beragam faktor. Mardikanto (1993) mengatakan adopsi terhadap inovasi dipengaruhi oleh variabel kependudukan, karakteristik teknologi, sumber informasi, pengetahuan, kesadaran, sikap dan pengaruh kelompok. Penelitian Burhansyah (2014) juga menjelaskan bahwa faktor yang mempengaruhi adopsi antara lain jarak ke lokasi usahatani, jarak ke sumber teknologi, tingkat pendidikan petani, luas lahan dan aksesibilitas ke sumber teknologi.

Zulvera (2014) menyebutkan bahwa tingkat adopsi petani berkaitan dengan pengetahuan, sikap, keterampilan dan persepsi petani tentang sistem pertanian organik yang diperoleh petani melalui proses belajar yang telah dilaluinya. Keberadaan dan dukungan dari penyuluhan sebagai proses pendidikan non formal, dukungan kebijakan pemerintah, lembaga penunjang kegiatan usahatani, dukungan sistem sosial akan mendorong petani untuk melaksanakan sistem pertanian organik dengan intensif.

Karakteristik inovasi juga turut mempengaruhi kecepatan proses adopsi inovasi 
(Rogers, 2010). Ciri yang pertama adalah keuntungan relatif (relative advantage), merupakan karakteristik inovasi yang memiliki keunggulan dibandingkan inovasi sebelumnya, baik secara ekonomis maupun secara teknis mudah untuk digunakan (Backer et al. 1986; Rogers 2010).

Penelitian ini termasuk kategori penelitian preskriptif. Dalam penelitian ini mencoba menyelesaikan masalah berdasarkan situasi kondisi faktual di lapangan. Terdapat beberapa point pertanyaan yang menjadi permasalahan yang dikaji dalam penelitian ini yaitu bagaimana penerapan SOP sistem pertanian organik yang dilakukan oleh petani sayuran organik di Kabupaten Bandung Barat serta faktor-faktor yang mempengaruhi petani dalam menerapkan SOP sistem pertanian organik.

\section{Metode Penelitian}

Objek dari penelitian ini adalah penerapan Standar Operasional Prosedur (SOP) sistem pertanian organik yang dilakukan oleh petani sayuran organik di Kabupaten Bandung Barat. Penelitian ini menggunakan metode penelitian kuantitatif, yaitu metode penelitian yang lebih menekankan pada aspek pengukuran serta objektif terhadap fenomena social. Dalam penelitian ini dilakukan pengukuran, setiap fenomena sosial dijabarkan dalam komponen masalah. Proses pengukuran menjadi hal sentral dalam penelitian ini.

Data yang digunakan dalam penelitian ini adalah data primer dan data sekunder. Data primer merupakan data yang diperoleh langsung dari petani sayuran organik di Kab.Bandung Barat. Data sekunder diperoleh dari Badan Pusat Statistik, data Dinas Pertanian Kabupaten Bandung Barat dan berbagai sumber lainnya. Teknik pengumpulan data dilakukan melalui :

1. Pengamatan langsung (observasi), yaitu pengamatan langsung dilakukan untuk melihat lokasi objek penelitian serta melakukan pengumpulan data sekunder

2. Wawancara (interview) dengan panduan kuesioner, yaitu melakukan komunikasi langsung secara verbal dengan menggali permasalahan

3. Focal Group discussion (FGD) untuk melihat dan mendengarkan langsung apa permasalahan yang dihadapi petani sayuran organic.

Untuk mendapatkan validitas yang tinggi, maka penentuan sampel sangat penting dalam penelitian ini. Populasi dalam penelitian ini adalah petani sayuran yang menerapkan pertanian organik di Kab.Bandung Barat, tepatnya di 3 kecamatan yaitu Lembang, Cisarua dan Parompong. Penentuan sampel dilakukan dengan metode cluster random sampling diambil sebanyak 35 petani secara acak dari masing-masing kecamatan tersebut, sehingga total sampel yang diteliti dalam penelitian ini adalah sebanyak 105 orang petani sayur organik.

Analisis data pada penelitian ini bertujuan untuk melihat hubungan dan pengaruh yang terjadi antar berbagai variabel untuk memperoleh jawaban atas pertanyaan penelitian. Data dianalisis dengan metode deskriptif dan metode inferensia.

Analisis deskriptif dilakukan dengan cara menggambarkan secara rinci data yang diperoleh dengan membuat tabulasi hasil jawaban responden lalu dipersentasikan. Analisis deskriptif dalam penelitian ini digunakan untuk menggambarkan penerapan pertanian organik di lokasi penelitian serta dibandingkan dengan SOP (SNI sistem pangan organik).

Untuk mengetahui faktor-faktor yang berpengaruh terhadap tingkat adopsi petani sayuran organik, dianalisis menggunakan analisis regresi linier berganda, dengan persamaan regresi sebagai berikut :

$$
\begin{aligned}
& Y=4,238+0,145 X_{1}+5,016 X_{2}+0,001 X_{3}-0,181 X_{4} \\
& +0,022 X_{5}+0,442 X_{6}+5,509 X_{7}+0,441 X_{8}+5,689 X_{9} \\
& +1,888 X_{10}+2,659 X_{11}
\end{aligned}
$$

Keterangan:

$\mathrm{Y}=$ Perilaku petani

$\boldsymbol{a}=$ Konstanta

$\mathrm{X}_{1}$ : Umur petani

$\mathrm{X}_{2}$ : Tingkat pendidikan petani

$\mathrm{X}_{3}$ : Luas penguasaan lahan

$\mathrm{X}_{4}$ : Pengalaman usahatani non organik

$\mathrm{X}_{5}$ : Pengalaman usahatani organik

$\mathrm{X}_{6}$ : Keikutsertaan petani dalam kegiatan penyuluhan / pelatihan

$\mathrm{X}_{7}$ : Persepsi petani terhadap keuntungan

relatifusahatani sayuran organik

$\mathrm{X}_{8}$ : Persepsi petani terhadap kesesuaian inovasi

$\mathrm{X}_{9}$ : Persepsi petanu terhadap kerumitan usahatani sayuran organik

$\mathrm{X}_{10}$ : Persepsi petani terhadap triability usahatani 
sayuran organik

$\mathrm{X}_{11}$ : Persepsi petani terhadap observability usahatani sayuran organik

$b$ : Koefisien Regresi

\section{Hasil dan Pembahasan}

\section{Karakteristik Petani Sayuran Organik di Kabupaten Bandung Barat}

Karakteristik petani berdasarkan jenis kelamin. Petani sayuran organic di lokasi penelitian sebagian besar adalah laki-laki (85\%). Secara tradisional laki-laki lebih berperan dalam mencari penghasilan. Meskipun demikian 15\% sisanya adalah petani wanita. Termasuk salah satunya adalah ketua poktan Semai Organik yaitu Bu YS.

Karakteristik petani oganik berdasarkan kelompok umur. Berdasarkan kelompok umur secara psikologis, petani sayur organik didominasi oleh kelompok umur produktif (18-54 tahun), yaitu sebanyak $87 \%$, sedangkan sisanya $13 \%$ petani berada pada ketegori umur tua. Golongan umur produktif merupakan kelompok yang potensial dalam melakukan suatu aktifitas. Pada rentang umur ini seseorang sedang berada pada kondisi fisik yang prima serta responsif pada setiap perubahan maupun inovasi (Sanjaya, 2015).

Karakteristikpetaniorganikberdasarkan tingkat pendidikan. Dilihat dari tingkat pendidikan terakhir yang ditempuh, mayoritas petani organik menempuh jenjang pendidikan hanya sampai SD dan SMP. Namun latar belakang pendidikan yang rendah tidak menjadi penghalang petani dalam menjalankan aktivitasnya (Sanjaya, 2015). Di Lain Pihak, Sumarwan (2003) mengatakan bahwa tingkat pendidikan menentukan seseorang dalam menerima pengetahuan dan informasi. Seseorang yang memiliki pendidikan yang baik akan lebih responsif terhadap informasi, yang pada akhirnya akan mempengaruhi pengambilan keputusan seseorang.

\section{Karakteristik petani organik berdasarkan} tingkat pendapatan. Pada penelitian ini yang dianalisis adalah besarnya pendapatan keluarga, yang artinya total seluruh pendapatan anggota keluarga. Sebagian besar petani organik $(65,2 \%)$ memiliki pendapatan perbulan rata-rata Rp. 2 juta sampai dengan Rp 3 juta. Jika dibandingkan dengan UMR Kabupaten Bandung Barat, pendapatan mereka sedikit di atas UMR.

\section{Kesesuaian Pelaksanaan Usahatani dengan SOP Pertanian Organik (SNI Sistem Pangan Organik)}

Kecamatan Parongpong, Cisarua dan Lembang merupakan kecamatan dengan jumlah petani organik yang cukup banyak di Kabupaten Bandung Barat. Sebenarnya jika menghitung jumlah petani sayuran yang menerapkan pertanian organik cukup sulit, mereka belum terdata dan terstruktur di Dinas Pertanian dan Hortikultura. Pertanian organik sendiri khusus untuk horti mulai masuk di tiga kecamatan tersebut sekitar tahun 2008. Untuk Kecamatan Parongpong dipelopori oleh Kelompok Tani Semai Organik. Mereka menanam 25 komoditas sayuran daun seperti bayam, kangkung, brokoli, wortel, bitt dan sebagainya. Anggota poktan Semai Organik yang menerapkan pertanian organik di tahun 2009 ada 14 orang. Sayangnya seiring waktu jumlah petani yang menerapkan pertanian organikberkurang. Pada tahun 2017 ini tercatat hanya 8 petani aktif yang menerapkan pertanian organik.

Pada dasarnya persepsi petani sendiri terkait pertanian organik umumnya sudah baik. Persepsi para organik tentang sayuran organik itu sendiri ada pada kategori baik. Artinya mereka menyadari bahwa organik itu sangat penting bagi kesehatan tubuh manusia, mereka meyakini bahwa system pertanian organik lebih memberikan manfaat bagi manusia dan lingkungan. Hanya ketika digali seputar pengetahuan tentang pertanian organik, pengetahuan responden masih beragam. Petani yang aktif di kelompok tani umumnya sudah mengetahui informasi tentang pertanian organik secara umum. Untuk Kecamatan Parompong terutama, di mana ada Poktan Semai Organik sebagai salah satu poktan pelopor pertanian organik di Bandung Barat, telah beberapa kali menyelenggarakan pelatihan pertanian organik.

Berdasarkan hasil penelitian didapatkan mayoritas petani pemahaman dan pengetahuannya terkait pertanian organik ini masih kurang. Mereka tahu pertanian organik tapi tidak banyak informasi yang mereka miliki, termasuk penerapan system pertanian organik itu seperti apa, masih banyak yang belum mengetahuinya. Apalagi petani petani tua yang sudah terbiasa dengan pertanian 
konvensional, mereka tidak memiliki motivasi atau keinginan untuk beralih ke sistem organik. Mereka mengganggap bahwa dengan menerapkan pertanian organik tidak memberikan tambahan keuntungan yang signifikan, bahkan yang ada hanyalah beban dan tanggung jawab untuk selalu menjaga kualitas. Selain itu mereka merasa pertanian organic sulit dan rumit penerapannya. Hal ini sejalan dengan penelitian Charina (2017) yang mengemukakan faktor yang mempengaruhi petani untuk maju memperluas skala usahanya diantaranya karena hambatan usia. Usia tua membuat seseorang enggan mencoba hal-hal baru. Pada usia tersebut seseorang lebih memilih untuk menikmati hidup dan nyaman dengan kebiasaan mereka.

Di lapangan juga terlihat bahwa petani mayoritas motivasinya terkait pertanian organik masih rendah. Faktor-faktor yang diduga mempengaruhi rendahnya tingkat motivasi mereka diantaranya karena kurangnya pemahaman tentang pertanian organik, tidak tahu prosedur, tidak tahu keuntungan yang didapat dll serta budaya/tradisi yang melekat pada diri mereka, yang sudah terbiasa berpuluh-puluh tahun menjalankan pertanian konvensional. Motivasi petani yang rendah akan mempengaruhi perilaku yang dijalankannya (Charina, 2017). Umumnya petani dengan motivasi yang tinggi cenderung untuk aktif serta responsif dengan adopsi inovasi. Sebaliknya petani dengan motivasi rendah cenderung pasif dan menolak kebaruan.

Untuk pasar organik, konsumen sebenarnya mengharapkan sayuran organiknya tersertifikasi (Indrasari, 2016). Sebenarnya untuk mendapatkan sertifikasi, SNI mengeluarkan SOP yang harus dipenuhi oleh setiap kelompok tani untuk memperoleh sertifikasi organik. Point-point yang tercantum dalam SOP tersebut adalah sebagai berikut :

1. Lahan dikonversi selama 2 tahun,

2. Lahan terpisah jauh dari lahan non organik lainnya,

3. Lahan tidak digunakan lagi untuk penanaman non organik,

4. Sumber air yang bebas dari kontaminasi bahan kimia,

5. Pupuk yang digunakan hanyalah pupuk organik,

6. Benih yang digunakan berasal dari tanaman organik,
7. Pengendalian hama penyakit dilakukana dengan pencegahan serta

8. Pasca panen tidak menggunakan bahan yang berbahaya

Penelitian di lapangan dengan cara membandingkan perilaku atau aktivitas pertanian organik yang dilakukan petani dibandingkan dengan SNI Sistem Pangan Organik, didapatkan tingkatan sebagaimana disajikan pada Tabel 1 .

Tabel 1. Tingkat Kesesuaian Pelaksanaan Usahatani dengan SOP Pertanian Organik (SNI Sistem Pangan Organik)

\begin{tabular}{lcc}
\hline \multicolumn{1}{c}{$\begin{array}{c}\text { Tingkat Kesesuaian } \\
\text { dengan SOP }\end{array}$} & $\begin{array}{c}\text { Jumlah } \\
\text { Responden } \\
\text { (orang) }\end{array}$ & $\begin{array}{c}\text { Persentase } \\
(\%)\end{array}$ \\
\hline $\begin{array}{l}\text { Tinggi } \\
\text { (terpenuhi 6-8 point SOP, } \\
\text { atau 75\%-100\%) }\end{array}$ & 14 & $13 \%$ \\
$\begin{array}{l}\text { Sedang } \\
\text { (terpenuhi 3-5 point SOP, } \\
\text { atau 37.5\%- 74.9\%) }\end{array}$ & 62 & $59 \%$ \\
$\begin{array}{l}\text { Rendah } \\
\text { (hanya memenuhi }<3\end{array}$ & 29 & $28 \%$ \\
$\begin{array}{l}\text { point SOP, atau kurang } \\
\text { dari 37.5\%) }\end{array}$ & & \\
\hline \multicolumn{1}{c}{ Total } & $\mathbf{1 0 5}$ & $\mathbf{1 0 0 \%}$ \\
\hline
\end{tabular}

Pada Tabel 1 dapat dilihat bahwa mayoritas petani organik perilakunya belum mencerminkan SOP yang ditetapkan oleh SNI Sistem Pangan Organik. Lebih dari 50\% petani hanya memenuhi 3-5 point SOP dari 8 point yang wajib diterapkan, yang berarti bahwa tingkat kesesuaian mereka dengan SOP ada pada kategori sedang. Bahkan sekitar 28\% petani hanya memenuhi kurang dari 3 point SOP, atau berada dalam kategori rendah.

Point yang belum terpenuhi mayoritas adalah point terkait lahan yang digunakan. 100\% dari responden tidak ada yang memenuhi point 1 dan 2 yaitu lahan harus dikonversi selama 2 tahun serta terpisah jarak $30 \mathrm{Km}$ dari lahan non organik. Hal tersebut tidak bisa dipenuhi karena menurut responden tidak bisa mengkonversi lahan selama 2 tahun, mereka beralasan jika lahannya tidak segera diolah, dari mana mereka akan mendapatkan penghasilan. Untuk point bahwa lahan harus 
terpisah jauh minimal $30 \mathrm{Km}$ dari lahan non organik dirasakan sulit oleh para petani karena kepemilikan lahan mereka hanya sempit sempit serta dengan jarak yang rapat rapat.

Untuk item penggunaan pupuk organik dan benih dari tanaman organik, serta perlakuan pasca panen tidak menggunakan bahan yang berbahaya sudah banyak diterapkan oleh para petani.

Berdasarkan hasil wawancara serta analisa di lapangan, terdapat juga beberapa poin penting yang menjadi kendala petani dalam menerapkan pertanian organik secara menyeluruh diantaranya.

1. Kurangnya fasilitator atau tenaga penggerak yang mampu memotivasi petani untuk lebih menerapkan pertanian organik

2. Daya dukung/ kemampuan yang dimiliki rendah atau tidak mencukupi, salah satunya tidak punya Green House

3. Kurangnya dukungan sarana prasarana dari pemerintah untuk menunjang pertanian organik.

4. Petani merasa bahwa pertanian organik ini rumit untuk dijalankan, mereka telah nyaman dengan kondisi budidaya konvensional yang selama ini mereka jalankan.

\section{Faktor-faktor yang Mempengaruhi Petani Sayuran Organik dalam Menerapkan SOP Sistem Pertanian Organik}

Pendugaan model faktor yang mempengaruhi petani sayuran organic dalam menerapkan SOP sistem pertanian organik diduga dengan metoda Ordinary Least Squares (OLS). Sebelum model digunakan maka dilakukan pengujian menurut kriteria statistik dan ekonometrik. Pengujian ekonometrik meliputi asumsi yang digunakan, pengujian ekonomi meliputi tanda dan besaran, sedangkan pengujian statistk meliputi uji statistik yang digunakan

\section{Pengujian Asumsi}

\section{A. Uji Asumsi Normalitas}

Uji normalitas dilakukan untuk mendeteksi apakah data yang digunakan berdistribusi normal atau tidak. Hasil uji normalitas menunjukkan data dapat dikatakan memenuhi persyaratan untuk analisis regresi linear berganda.

\section{B. Uji Asumsi Multikolinearitas}

Uji kolinearitas dilakukan untuk mengetahui apakah ada collinearity atau tidak di antara variabel bebas. Dari hasil perhitungan diketahui bahwa tidak terjadi multikolinieritas dalam model garis regresi berganda.

C. Uji Asumsi Heteroskedasitas

Hasil analisis menunjukkan data bersifat homoskedastisitas/ tidak terjadi heteroskedastisitas dan memenuhi persyaratan untuk analisa regresi.

\section{Hasil Dugaan Faktor yang Mempengaruhi Petani dalam Menerapkan SOP Sistem Pertanian Organik}

Hasil Uji F menunjukkan bahwa secara simultan variabel umur (X1), tingkat pendidikan (X2), pengalaman usahatani sayuran konvensional (X3), pengalaman usahatani sayuran organik (X4), luas penguasaan lahan (X5), keikutsertaan dalam kegiatan penyuluhan (X6), karakteristik inovasi yang meliputi variabel keuntungan relatif (X7), tingkat kerumitan (X8), triability (X9), observability (X10), dan kesesuaian inovasi (X11) berpengaruh signifikan terhadap keputusan petani dalam menerapkan SOP sistem pertanian organik (Y).

Nilai $r=0,776$ menunjukkan hubungan yang sangat kuat. Sementara, nilai koefisien determinasi adalah $60,3 \%$ yang berarti perilaku petani dalam menerapkan SOP budidaya sayuran organik dapat dijelaskan sebesar $60,3 \%$ oleh keragaan variabel variabel umur (X1), tingkat pendidikan (X2), pengalaman usahatani sayuran konvensional (X3), pengalaman usahatani sayuran organik (X4), luas penguasaan lahan (X5), keikutsertaan dalam kegiatan penyuluhan (X6), karakteristik inovasi yang meliputi variabel keuntungan relatif (X7), tingkat kerumitan (X8), triability (X9), observability (X10), dan kesesuaian inovasi (X11), sedangkan sisanya $39,7 \%$ dipengaruhi oleh faktor lain yang tidak diteliti. Hasil tersebut menunjukkan model tersebut dinyatakan cukup baik.

Sementara hasil uji parsial menunjukkan variabel tingkat pendidikan petani, keikusertaan petani dalam kegiatan penyuluhan, persepsi petani terhadap keuntungan relatif, persepsi petani terhadap kerumitan dan observability sistem pertanian organik merupakan faktor yang berpengaruh terhadap keputusan petani dalam menerapkan SOP 
Tabel 2. Hasil Uji Regresi Faktor-faktor Yang Mempengaruhi Petani dalam Menerapkan SOP Sistem Pertanian Organik

\begin{tabular}{lccc}
\hline \multicolumn{1}{c}{ Variabel } & Koefisien & Standard Error & Significant \\
\hline Konstanta & 4,238 & 1,970 & 0,049 \\
Umur & 0,145 & 0,177 & 0,415 \\
Tingkat Pendidikan Petani & 5,016 & 1,521 & $0,001^{* *}$ \\
Luas Penguasaan Lahan & 0,001 & 0,000 & 0,126 \\
Pengalaman Usahatani Sayuran Konvensional & 0,181 & 0,364 & 0,621 \\
Pengalaman Usahatani Sayuran Organik & 0,022 & 0,319 & 0,945 \\
Keikutsertaan dalam Kegiatan Penyuluhan/Pelatihan & 0,442 & 2,608 & $0,005^{* *}$ \\
Persepsi Petani Terhadap Keuntungan Relatif & 5,509 & 1,418 & $0,000^{* *}$ \\
Persepsi Petani Terhadap Kesesuaian Inovasi & 0,441 & 1,482 & 0,767 \\
Persepsi Petani terhadap Kerumitan & 5,689 & 1,405 & $0,000^{* *}$ \\
Persepsi Petani terhadap triability & 1,888 & 1,497 & 0,211 \\
Persepsi Petani terhadap Observability & 2,659 & 1,538 & $0,087^{*}$ \\
\hline
\end{tabular}

Keterangan: ${ }^{* *}$ Sign pada $\alpha<0,05,{ }^{*}$ Sign pada $\alpha<0,1$

sistem pertanian organik (Tabel 2).

Hasil analisis regresi pada Tabel 2 menunjukkan bahwa tingkat pendidikan petani, keikusertaan petani dalam kegiatan penyuluhan, persepsi petani terhadap keuntungan relatif, persepsi petani terhadap kerumitan dan observability sistem pertanian organik berpengaruh positif dan signfikan terhadap keputusan petani dalam menerapkan SOP sistem pertanian organik. Hal ini menunjukkan bahwa semakin baik tingkat pendidikan petani, semakin sering petani ikut dalam kegiatan penyuluhan, semakin besar keuntungan yang dirasakan petani dalam mengusahakan sayuran organik, semakin mudah petani membudidayakan sayuran organik, serta semakin mudah petani dalam mengamati perbedaan hasil budidaya sayuran organik dan konvensional, maka terdapat kecenderungan petani akan membudidayakan sayuran organik sesuai dengan SOP.

Beberapa hasil penelitian menunjukkan faktor sosiodemografis seperti umur, gender, dan tingkat pendidikan turut mempengaruhi petani dalam mengadopsi sebuah inovasi (Kabadi, 1999; Hassan, 2009). Tingkat pendidikan formal berpengaruh signifikan terhadap keputusan petani dalam menerapkan SOP sayuran organik. Soekartawi (1998) menyebutkan bahwa petani dengan pendidikan lebih tinggi relative lebih cepat dalam mengadopsi sebuah inovasi. Sebagian besar petani sayuran organic di lokasi penelitian memiliki tingkat pendidikan yang relatif baik, yaitu setingkat SMA dan beberapa orang menempuh pendidikan hingga tingkat sarjana. Tingkat pendidikan berhubungan dengan pengetahuan dan kemampuan petani dalam menganalisis berbagai informasi sebelum menerapkan budidaya sayuran organik. Beberapa hasil penelitian juga menunjukkan bahwa tingkat pendidikan berpengaruh terhadap keputusan petani dalam mengadopsi sebuah inovasi (Susanti, 2008; Putri \& Sulistyaningsing, 2014). Penelitian Warford (2010) juga mengemukakan bahwa pengetahuan dan pendidikan seseorang sangat mempengaruhi kemampuannya dalam mengadopsi sebuah inovasi.

Keikutsertaan petani dalam kegiatan penyuluhan berpengaruh signifikan terhadap keputusan petani dalam menerapkan SOP sayuran organik. Kegiatan penyuluhan sebagai bagian dari kegiatan pendidikan non formal dapat menambah pengetahuan, merubah sikap dan keterampilan petani dalam membudidayakan sayuran organik. Beberapa kajian menunjukkan bahwa kegiatan penyuluhan berpengaruh signifikan terhadap perilaku petani dalam mengadosi teknologi baru (Ali \& Rahut, 2013). Menurut Ukaejiofo (2013) dalam tulisannya menemukan bahwa penyuluhan terutama melaluli metode demonstrasi berpengaruh terhadap perilaku petani dalam mengadop inovasi, umumnya mereka tergugah jika melihat demonstrasi 
langsung yang berhasil oleh penyuluh. Indraningsih (2011) menyebutkan persepsi petani terhadap kegiatan penyuluhan berpengaruh signifikan terhadap keputusan petani untuk mengadopsi Inovasi. Kegiatan penyuluhan yang intensif dapat membentuk persepsi petani terhadap manfaat penyuluhan. Lebih lanjut lagi, tingkat partisipasi petani dalam kegiatan penyuluhan juga turut berpengaruh terhadap tingkat adopsi inovasi petani (Pan, 2014; Etehadi et al, 2011; Rezfanvar, 2011). Sebagian petani di lokasi penelitian mengatakan belum merasakan peran kegiatan penyuluhan dalam sistem pertanian organik. Petani lebih banyak belajar mengenai sistem pertanian organik dari petani lainnya. Kegiatan dan materi penyuluhan dari pemerintah memang belum difokuskan pada usahatani sayuran organik, sehingga kadang-kadang petani menemui kendala dalam teknis budidaya sayuran organik.

Suatu inovasi dapat diterima atau tidak oleh petani, dilihat dari aspek : (1) nilai-nilai sosiobudaya, (2) ide-ide yang telah diperkenalkan sebelumnya, dan/atau (3) kebutuhan petani akan inovasi (Indraningsih, 2011). Persepsi petani terhadap inovasi akan menentukan tingkat pengambilan keputusan terhadap inovasi (Susanto, 1977). Beberapa hasil penelitian menunjukkan persepsi petani terhadap karakteristik inovasi berpengaruh signifikan terhadap keputusan petani dalam mengadopsi inovasi (Adesina et al, 1995; Adesina et al, 1993, Ismiaili et al, 2015, Kabadi et al, 1999, Panggabean et al, 2016, Schneeberger et al, 2002, Vanclay \& Lawrence, 1994).

Karakteristik inovasi yang pertama adalah keuntungan relatif (relative advantage), merupakan karakteristik inovasi yang memiliki keunggulan dibandingkan inovasi sebelumnya, baik secara ekonomis maupun secara teknis mudah untuk digunakan(Backeretal.1986; Rogers 2003; Simpson 2002). Hasil analisis menunjukkan persepsi petani terhadap keuntungan membudidayakan sayuran organik berpengaruh signifikan terhadap keputusan petani dalam menerapkan SOP sistem pertanian organik (Tabel 2). Apabila petani merasakan keuntungan dari usahatani sayuran organik maka terdapat kecenderungan petani membudidayakan sayuran organic sesuai dengan SOP. Sebagian besar petani $(71,43 \%)$ menilai sistem budidaya sayuran organic memerlukan tenaga kerja yang lebih banyak, curahan waktu yang lebih tinggi, biaya usahatani yang lebih tinggi. Hal tersebut akhirnya mempengaruhi petani dalam menerapkan SOP sistem budidaya pertanian organik. Pada saat awal petani beralih dari sistem budidaya sayuran konvensional ke sayuran organik, petani mengaku pendapatannya berkurang, karena produktivitas tanaman juga menurun. Namun setelah kondisi tanah telah dapat menyesuaikan dengan sistem pertanian organik, petani merasakan pendapatan yang diterima lebih tinggi karena harga sayuran organik yang diterima petani lebih tinggi dibandingkan dengan sayuran konvensional. Hasil penelitian da Costa (2002), Mulyaningsih (2012) juga menunjukkan bahwa usahatani organik berpengaruh nyata terhadap pendapatan petani. Hal tersebut lah yang mempengaruhi keputusan petani untuk membudidayakan sayuran organik. Meskipun menurut sebagian petani, kadang-kadang harga sayuran organik tidak berbeda jauh dengan sayuran konvensional, akibatnya petani tidak sepenuhnya menerapkan SOP sistem sayuran organik.

Karakteristik yang kedua adalah kesesuaian (compatibility), baik dengan kebutuhan petani, norma dan nilai ataupun pengalaman di masa lalu (Backer et al. 1986). Hasil analisis menunjukkan persepsi petani terhadap kesesuaian inovasi tidak berpengaruh terhadap penerapan SOP sistem pertanian organik (Tabel 2). Hampir seluruh petani menyatakan bahwa alasan mereka untuk membudiayakan sayuran organik adalah untuk memenuhipermintaan pasarakan produk organik, dan juga ada sebagian petani yang menyadari pentingnya menjaga kelestarian lingkungan, sehingga mereka beralih menerapkan sistem pertanian organik yang ramah terhadap lingkungan. Namun ada beberapa hal yang menjadi hambatan teknis yang dirasakan petani untuk sepenuhnya menerapkan SOP sistem pertanian organik, diantaranya adalah jarak dengan lahan lain yang masih menerapkan sistem pertanian konvensional. Sebagian besar petani juga menemui hambatan dalam proses sertifikasi organik yang dirasakan cukup rumit dan mahal. Permasalahan yang sama juga dihadapi oleh petani di Iran di mana kesulitan dalam proses sertifikasi menurunkan motivasi petani untuk menerapkan sistem pertanian organik (Soltani et al, 2013).

Karakteristik inovasi yang ketiga adalah tingkat kerumitan (complexity) yang menentukan kecepatan adopsi inovasi, semakin mudah sebuah 
inovasi untuk diterapkan, semakin cepat petani mengadosi inovasi tersebut (Rogers, 2010). Hasil analisis menunjukkan persepsi petani terhadap kerumitan sistem budidaya sayuran organik berpengaruh signifikan terhadap keputusan petani dalam menerapkan SOP sayuran organik (Tabel 3). Semakin petani merasa tidak kesulitan dalam melakukan budidaya sayuran organic termasuk dalam membuat pupuk dan pestisida nabati, maka petani cenderung menerapkan budidaya sayuran organik sesuai dengan SOP. Sebagian kecil petani kadang-kadang tidak sabar dengan pertumbuhan sayuran organik yang lambat, merasa rumit dalam pembuatan pupuk dan pestisida nabati, sehingga kadang-kadang petani masih menggunakan pupuk dan pestisida kimiawi dalam budidaya sayuran organik, meskipun dalam dosis yang rendah. Hal ini sejalan dengan hasil penelitian Vanclay \& Lawrence (1994), yang menyebutkan bahwa tingkat kerumitan dapat menjadi penghambat bagi petani untuk menerapkan sebuah inovasi.

Karakteristik inovasi yang keempat adalah dapat dicoba (triability), apakah inovasi tersebut dapat diujicoba dan mudah digunakan oleh petani (Rogers, 2010). Sedangkan ciri inovasi yang kelima adalah dapat diamati (observability), merupakan suatu tingkat di mana inovasi dapat diamati oleh orang lain (Backer et al. 1986, Rogers, 2010). Hasil analisis menunjukkan tingkat keteramatan (observability) berpengaruh signifikan terhadap keputusan petani dalam menerapkan SOP sistem pertanian organik. Semakin mudah petani dalam mengamatiperbedaan hasil budidaya sayuran organik dan konvensional, maka terdapat kecenderungan petani akan membudidayakan sayuran organik sesuai dengan SOP. Dalam memasarkan sayuran organik, sebagian besar petani sudah memiliki pasar tetap yaitu penampung yang memasarkan ke pasar swalayan. Sedangkan untuk sayuran non organik petani biasanya memasarkannya ke bandar yang akan menjual ke pasar tradisional. Namun apabila hasil panen sayuran organik tidak terserap oleh penampung pasar swalayan, petani menjualnya ke bandar dengan harga yang sama dengan sayuran non organik. Dalam hal pemasaran inilah yang terkadang menjadi penghalang bagi petani untuk menerapkan budidaya sayuran organik sesuai dengan SOP. Hal ini karena petani merasa korbanan yang telah dikeluarkan untuk mengusahakan sayuran organik tidak sebanding dengan hasil yang diperoleh. Soltani et al (2013) mengatakan bahwa hambatan yang sering ditemui dalam sistem pertanian organik adalah dalam hal pemasaran, proses sertifikasi dan akses terhadap informasi mengenai sistem pertanian organik. Hal tersebut merupakan masalah yang umum dijumpai di negara berkembang.

\section{Kesimpulan}

Sebagian besar petani sayuran organik di Kabupaten Bandung Barat belum sepenuhnya menerapkan sistem budidaya sayuran organik sesuai SNI sistem pangan organik. Tingkat pendidikan petani, keikusertaan petani dalam kegiatan penyuluhan, persepsi petani terhadap keuntungan relatif, persepsi petani terhadap kerumitan dan observability sistem pertanian organik berpengaruh positif dan signifikan terhadap keputusan petani dalam menerapkan SOP sistem pertanian organic.

Agar petani mau menerapkan sistem budidaya sayuran organik sesuai dengan SOP perlu dukungan dari berbagai pihak, baik instansi pemerintah, lembaga pemasaran dan lembaga penyuluhan agar petani dapat meningkatkan pengetahuan dan juga keterampilan dalam hal membudidayakan sayuran organik serta merasakan keuntungan dari usahatani sayuran organik.

\section{Ucapan Terima Kasih}

Terima kasih kami ucapkan kepada Universitas Padjadjaran yang telah memberikan dukungan dana untuk melaksanakan penelitian ini melalui skema Riset Fundamental Unpad

\section{Daftar Pustaka}

Adesina AA, Zinnah MM. 1993. Technology Characteristics, Farmers' Perceptions and Adoption Decisions: A Tobit Model Application in Sierra Leone. Agricultural Economics, 9(4) : 297-311.

Adesina AA, Forson JB. 1995. Farmers' Perceptions and Adoption of New Agricultural Technology: Evidence From Analysis in Burkina Faso And Guinea, West Africa. Agricultural Economics, 13(1) : 1-9. 
Adesina AA, Mbila D, Nkamleu GB, Endamana D. 2000. Econometric Analysis of the Determinants of Adoption of Alley Farming by Farmers in the Forest Zone of Southwest Cameroon. Agriculture, Ecosystems \& Environment Journal, 80(3) : 255-265.

Ali A, Rahut DB. 2013. Impact of Agricultural Extension Services on Technology Adoption and Crops Yield: Empirical Evidence from Pakistan. Asian Journal of Agriculture and Rural Development, 3(11) : 801-812.

Backer TE, Liberman RP, Kuehnel TG. 1986. Dissemination and Adoption of Innovative Psychosocial Interventions. Journal of Consulting and Clinical Psychology, 54(1) : 111-118.

Burhansyah R. 2014. Faktor-Faktor yang Mempengaruhi Adopsi Inovasi Pertanian Pada Gapoktan Puap dan Non Puap di Kalimantan Barat (Studi Kasus: Kabupaten Pontianak Dan Landak). Jurnal Ilmu Pertanian, 23(1) : 7-15.

Charina A, Kusumo RAB, Sadeli AH. 2017. Penerapan Teknologi Informasi dan Komunikasi pada Agribisnis Sayuran Organik. Jurnal Agricore, 2(2) : 10-17.

Da Costa A. 2012. Can Organic Farming Enhance Livelihoods for India's Rural Poor?.[Internet] dapat diunduh di http://www.guardian. co.uk/ global-development].

Etehadi M, Rusta K, Gholi-Nia MJ. 2011. Investigating the Effectiveness of FFS Aproach in Disseminating IPM Practices from Farmers' Overview, Case Study Sistan and Baluchestan Province. Iranian Agricultural Extension and Education Journal, 7(1) : 41-52.

Indrasari A. 2016. Persepsi Konsumen terhadap Sayuran Organik. [Skripsi]. Malang (ID): Universitas Brawijaya.

Indraningsih KS. 2011. Pengaruh Penyuluhan Terhadap Keputusan Petani dalam Adopsi Inovasi Teknologi Usahatani Terpadu. Jurnal Agro Ekonomi, 29(1) : 1-24.

Ismialaili, Purnaningsih N, Asngari PA. 2015. Tingkat Adopsi Inovasi Pengelolaan Tanaman Terpadu (PTT) Padi Sawah di Kecamatan Leuwiliang Kabupaten Bogor. Bogor (ID): Jurnal Penyuluhan, 11(1) : 49-59.

Kabadi A, PannelDJ. 1999. AConceptual Framework of Adoption of an Agricultural Innovation.
Agricultural Economics, 21(2) : 145-154.

Mardikanto T. 1993. Penyuluh Pembangunan Pertanian. Surakarta (ID): Sebelas Maret University Press.

Mulyaningsih A. 2010. Analisis Pendapatan Usahatani Padi Organik Metode SRI (System of Rice Intensification); Studi Kasus Desa Cipeuyeum, Kecamatan Haurwangi, Kabupaten Cianjur, Provinsi Jawa Barat. [Skripsi]. Bogor (ID) : Institut Pertanian Bogor.

Pan, Dan. 2014. The Impact of Agricultural Extension on Farmer Nutrient Management Behavior in Chinese Rice Production : A Household-Level Analysis. Journal Sustainability, 6, 6644-6665.

Panggabean MT, Amanah S, Tjitropranoto P. 2016. Persepsi Petani Lada terhadap Diseminasi Teknologi Usahatani Lada di Bangka Belitung. Bogor (ID): Jurnal Penyuluhan, 12(1) : 62-73.

Putri, Gijayana AK, Sulistyaningsih. 2014. Analisis Faktor-Faktor yang Mempengaruhi Keputusan Petani dalam Menerapkan Usahatani Padi Organik. [Internet] dapat diunduh di jurnal. unars.ac.id/artikel/2014]

Rezvanfar A, Eraktan G, Olhan E. 2011. Determine of Factors Associated with Adoption of Organic Agriculture Among Small Farmers in Iran. Africal Journal of Agricultural Research, 6(13) : 2950-2956

Rogers EM. 2010. Diffusion of Innovations $\left(4^{\text {th }}\right.$ edition). New York: The Free Press.

Sanjaya R. 2015. Faktor Yang mempengaruhi Adopsi Inovasi Petani. Surabaya (ID): Angkasa Jaya.

Schneeberger W, Darnhofer I, Eder M. 2002. Barriers to the Adoption of Organic Farming by CashCrop Producers in Austria. American Journal of Alternative Agriculture, 17(1) : 24-31.

Soekartawi. 1998. Prinsip Dasar Komunikasi Pertanian. Jakarta (ID): UI Press.

Soltani S, Azadi H, Mahmoudi H, Witlox F. 2013. Organic Agriculture in Iran : Farmers' Barriers to and Factors Influencing Adoption. Renewable Agriculture and Food System Journal, 29 (2) : 126-134.

Susanti, Lisiana W, Sugihardjo, Suwarto. 2008. Faktor-faktor yang Mempengaruhi Pengambilan Keputusan Petani dalam Penerapan Pertanian Padi Orgaik di Desa Sukorejo, Kecamatan Sambirejo, Kabupaten Sragen. Jurnal Agritext 
24(1) : 1-14.

Susanto. 1977. Komunikasi Kontemporer. Jakarta (ID) : Binacipta.

Suwarman. 2002. Perilaku Konsumen : Teori dan Penerapannya dalam Pemasaran. Jakarta (ID): Ghalia Indonesia.

Ukaejiofo R. 2013. Effect of Extension Programs on Adoption of Improved Farm Practices by Farmers in Adana, Southern Turkey. Journal of Biology, Agriculture and Healthcare, 3(15): 6992.

Vanclay F, Lawrence G. 1994. Farmer Rationality and the Adoption of Environmentally Sound Practices; A critique of the Assumptions of Traditional Agricultural Extension European Journal of Agricultural Education and Extension, 1(1) : 59-90.

Warford, Mark K. 2010. Testing a Diffusion of Innovations in Education Model. The Innovation Journal: The Public Sector Innovation Journal. 10 (3): 1-28.

Zulvera. 2014. Faktor Penentu Adopsi Sistem Pertanian Sayuran Organik dan Keberdayaan Petani di Provinsi Sumatera Barat. [Disertasi]. Bogor (ID) : Institut Pertanian Bogor. 